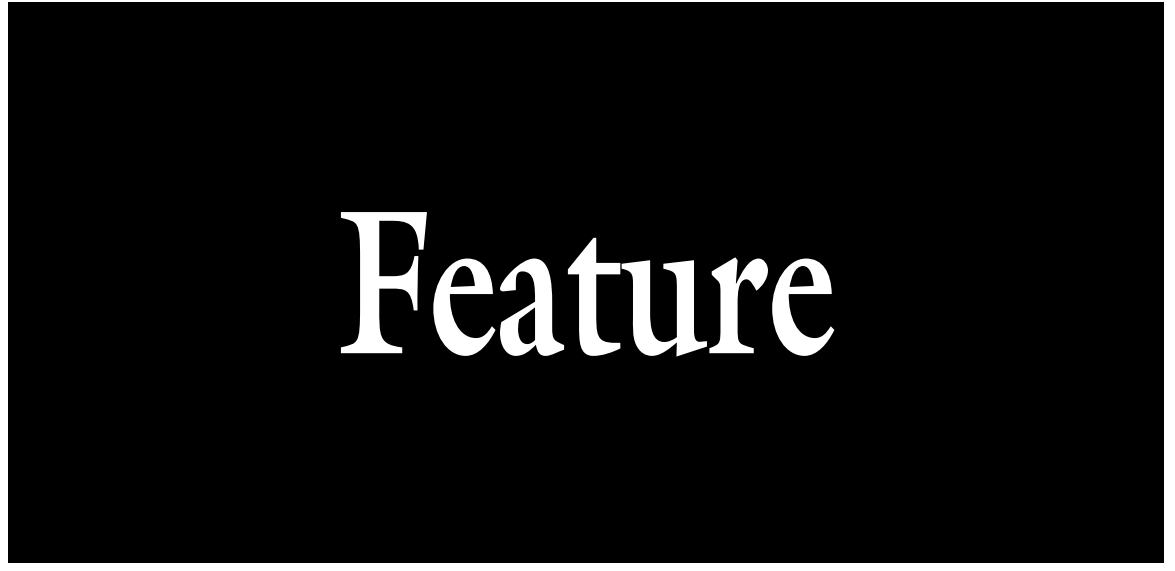

\section{Loss and Recovery of Research Investment for Applied Sciences: A Salutary Lesson from New Zealand}

\section{M.B. Kirkham ${ }^{1}$ and B.E. Clothier}

ADDITIONAL INDEX WORDs. science policy, traditional agricultural sciences, soil and land-use sciences, National Association of State Universities and Land-Grant Colleges

SUMMARY. In 1992, all governmental resourcing and investment in New Zealand, including that for science, underwent dramatic reform. The global philosophy driving the reform was new public management - a method by which nations could be run more economically by emulating the commercial world. Central to the reform was separation of policy, purchasing (investment), and providers (in the case of research scientists). The reform led to a large reduction in the number of governmental scientists. For example, in 1 year alone, 2001-2002, the Horticultural and Food Research Institute, one of the nine governmental branches of science, lost 51 staff members, $10 \%$ of its work force. Over a decade later after the establishment of the reform, in July 2003, the New Zealand government's investment agency announced its budget for the next 6 years. The governmentfunded science sectors considered to do modern research such as computer technology and biotechnology, and halved funding for land-related sciences. The reduced budget dramatically limited New Zealand's capacity for research in soil and land-use science and ended all research positions in this area (38 jobs). Public outcry through newspaper editorials and from leading businessmen, along with effective leadership from the scientific community, led to the reestablishment of funding in the form of a virtual national center called Sustainable Land Use Research Initiative (SLURI). The elimination of funding for soil and land-use science research in New Zealand was an unexpected and potentially disastrous result of new public management. New Zealand's experience has relevance for the United States, because budgets for agricultural research are being severely reduced or converted to competitive funding. The U.S. President's fiscal year 2006 budget proposed to cut formula funding by $50 \%$ and to zero it out in fiscal year 2007 . The funds would have been put in competitive grants. In New Zealand, the lack of ability to respond to a scientific problem demonstrated that a balance must be maintained in funding decisions so that scientific capability is retained to solve unforeseen future problems.
$\mathrm{F}$ unding for agricultural research in New Zealand has undergone dramatic change in the last 3 years. As described in this article, the government of New Zealand halved funding for soil- and land-related sciences in July 2003. The decision meant the end of most of soil and land-use research in New Zealand. Through public outcry and effective leadership, governmental investment was reinstated. New Zealand's experience has relevance for the U.S., because federally funded research for production agriculture is precarious. The U.S. President's fiscal year 2006 budget proposed cuts over 2 years for the U.S. Department of Agriculture (USDA). As noted later, the proposed cuts in the agricultural budget were not made as a result of efforts from agricultural administrators. Overall, the cut for research and development in the U.S. was $14.6 \%$ reducing its budget to \$2.1 billion (Cerf and Miller, 2005). Cuts strongly and negatively affect production agriculture and the infrastructure that supports agricultural and environmental sciences at the land-grant universities. This results in loss of graduate students, multistate research projects, and extension, which rely on research-based information as well as teaching that incorporates current findings into lectures. In the past, the U.S. has been a world leader in science, including production agriculture, through its investment in long-term research and development and cutting-edge technologies. However, now our investments in research and development (R\&D) funding, outside of defense and health care, are essentially flat (Pelosi, 2006). Budget cuts are downsizing traditional agricultural science, including horticulture (Cloyd, 2005). Despite the unprecedented growth in the size, diversity, and value of the horticultural industry worldwide, horticultural science is experiencing a crisis. The number of horticultural science departments at North American universities has declined $35 \%$ over

Department of Agronomy, Kansas State University, Manhattan, KS 66506-5501 and The Horticultural and Food Research Institute of New Zealand Ltd. (HortResearch), Private Bag 11-030, Palmerston North, New Zealand

The senior author thanks the College of Agriculture at Kansas State University for an NSF ADVANCE award for travel to New Zealand to study its science policy and thanks Dr. Fred A. Cholick, Dean of the College of Agriculture at Kansas State University and Director of the Kansas Agricultural Experiment Station for a personal interview on 3 July 2006, in which he told of the efforts that have been undertaken to reverse the Presidential budget proposals. We also thank Dr. Paul W. Gandar, Ministry of Economic Development, Wellington, for comments on the paper and pointing out Ashby's law of requisite variety.

This is contribution no. 06-348-J from the Kansas Agricultural Experiment Station.

${ }^{1}$ Corresponding author. E-mail: mbk@ksu.edu 
the last 30 years (M.W. Neff, unpublished data). This article provides horticultural scientists with experience from New Zealand, which might be used as a strategy for strengthening production agriculture in the U.S. and preserving publicly funded science.

The New Zealand Department of Scientific and Industrial Research (DSIR), established in 1926, carried out most of New Zealand's publicly funded science until 1989 when it was disestablished. During its years of operation, DSIR, like other branches of government (including health and education), set and carried out policy. DSIR had three roles: it set policy, it received monies for scientific research that its policy determined, and its scientists provided the research.

In the 1980s, critics proclaimed that central government was too large, consumed too many resources, and provided poor return on investment. New public management is a generic term for reform that emulates the commercial world. New public management practices drawn from private-sector management and applied to the public sector would result in increased efficiency (Boden et al., 2004). Thus, beginning in the early 1990s, governmental research establishments and other governmental agencies in New Zealand (and in the U.K.) were subjected to a rapid policy-initiated transformation. In New Zealand, a monetary crisis enabled a small group of ministers in the elected government, and public servants, to centralize power and initiate sweeping reforms. As budgets were squeezed, governments of New Zealand and the U.K. put emphasis on the three E's: economy (in the old domestic sense of spending little), efficiency, and effectiveness.

The Ministry of Research, Science and Technology (MoRST) was established on l Oct. 1989 by the cabinet of New Zealand and took part in the reforms of the New Zealand science system. The cabinet is part of the New Zealand government, which is a parliamentary democracy. It is unicameral with a House of Representatives, commonly called Parliament. The chief of state is Queen Elizabeth represented by the Governor General. The head of government is the Prime Minister. The cabinet is an Executive Council appointed by the Governor General on the recommendation of the Prime Minister (U.S. Central Intelligence Agency, 2006). The separation of policy, purchasing (investment), and providers (civil servants) into three independent entities (the three P's) was central to new public management reform. MoRST develops science and technology policy. The Foundation for Research, Science and Technology (FRST) is the major purchaser of public good science. The Crown Research Institutes (CRIs) and universities provide most of the public research and development. Thus, policy is set by MoRST, FRST purchases research to carry out the policy, and the CRIs and universities provide the research. The overall goal of investment in research, science, and technology is to benefit the lives, environments, and enterprises of all New Zealanders (Ministry of Research, Science and Technology, 2006).

There are nine universities in New Zealand, but only two do agricultural research: Lincoln University, near Christchurch, and Massey University in Palmerston North. There are nine CRIs: AgResearch, Crop and Food Research, Institute of Environmental Science and Research (ESR), Forest Research, Institute of Geological and Nuclear Sciences (GNS), HortResearch, Industrial Research, Landcare Research, and the National Institute of Water and Atmospheric Research (NIWA). No CRI is specifically designated to study soil and land care. Rather, these skills are distributed across several CRIs. Of the nine, only three do not have any soil or land-use science responsibilities (ESR, GNS, and Industrial Research).

University researchers receive their salaries through "vote education" (a "vote" in New Zealand is like a bill in the Congress of the U.S.). They tend to focus on students, both undergraduate and graduate. Scientists at the CRIs work on a zero-base funding; essentially there is no direct allocation from government. New Zealand is unique in that all of its public science funding is contestable. That is, the scientists have to raise the money for their salaries and research through competitive grants. No other country in the Organization for Economic Cooperation and Development [OECD (a group of the world's 30 most developed nations)] funds research in this way (Tallon, 2005).
The funding from FRST, and other commercial work, pays the salaries of the CRI scientists. If they have no funding, they have no salary and no job (Judd, 2005). As a consequence, scientists at CRIs have limited job stability.

The CRIs, formed in 1992, are government-owned research businesses and incorporated companies registered under the Companies Act. Each business must be profitable to remain in business. The performance of the businesses (CRIs) is reported quarterly to the government, and boards oversee each CRI. Quarterly reporting is a requirement of the Public Finance Act. Profits can be held by CRIs as retained earnings to invest in their own infrastructure and people.

After the CRIs were formed, there were large reductions in numbers of scientists. For example, for AgResearch, governmental funding dropped 36\% between 1992 and 2004 , and revenue was New Zealand (NZ) \$14.4 million below budget in 2004. Forest Research lost 20 staff in 2003-2004. HortResearch lost 51 staff in 2001-2002 (528 to 477 or $10 \%$ of its work force). The new chief executive officer (CEO) of HortResearch (since 2002), P. McGilvary (a businessman), stressed that capability must be retained and no more staff have been lost since 2002 .

On 30 July 2003, FRST announced its investment decisions for the next 6 years. It funded three "glamorous sectors" (the term is used by Dann, 2003): information and computer technology, innovative industries, and biotechnology. The decision reflected the "growth through innovation" policy of the government. The "old economy" agricultural research was cut, including all viticultural and bee research. The support for soil science was halved (NZ \$6 million to NZ \$3 million). Seven million dollars (NZ) were lost across the six CRIs that did soil and land-use science. Thirty-eight fulltime equivalent (FTE) positions were at risk in the CRIs. Lincoln University, the only university conducting agricultural research under FRST, had its program ended.

The loss of money for soil and land-use science was seen by many as a disaster. Soils and land-care are keys to the New Zealand economy. 
Seventeen percent of New Zealand's gross domestic product depends on the top $15 \mathrm{~cm}$ (5.9 inches) of soil (Williams et al., 2005). Failure to sustain soil resources put NZ \$2.16 billion of the gross domestic product at risk. Soils are irreplaceable. "We can no more manufacture soil with a tank of chemicals than we can invent a rain forest, or create a single bird" (Hawken et al., 1999, p. 204).

The response to FRST's funding decisions was immediate and widespread from many different sectors of the society: newspaper editorials, influential agricultural business, the New Zealand Soil Science Society (a member of the International Union of Soil Science), Regional Councils (similar to the environmental protection agencies of U.S. states), and the CEOs of the affected CRIs, but they did not express their concern in public.

The first strong, and unlikely, ally was the most influential metropolitan newspaper in the country, the New Zealand Herald, published in Auckland. It blasted the government's funding decision. It said, "It is hard to imagine more productive uses of science in this country than research into soil. Our economic dependence on agriculture remains undiminished by a 30 -year quest for a more diverse range of exports. And our soil is not a resource that can ever be taken for granted. Its constant requirements for fertiliser and its tendency to erosion are reasons alone to maintain efforts to improve the soil's quality and stability. So it is hard to understand why the Government's granting agency, the Foundation for Research, Science and Technology, has suddenly halved the money it allocates to soil science, and easy to understand the dismay of scientists whose work will be cut short, or possibly taken overseas if their projects are applicable to soil elsewhere" (The New Zealand Herald, 2003).

Another article in the New Zealand Herald said, "Land-based industries could be missing out on crucial research dollars as public funding gets diverted to more glamorous sectors such as biotechnology. Those sentiments will ring true to many of the primary sector researchers who have missed out in the latest round of funding by the Government's Foundation for Research, Science and Technology" (Dann, 2003). Another article in the New Zealand Herald said, "The Government's main science funding agency has halved its support for soil science, threatening to drive some of New Zealand's 'giants' of research overseas. Society of Soil Science president Peter Stephens says that the cut, from $\$ 6$ million to $\$ 3$ million a year, is 'devastating and potentially irrecoverable.' It [the cut] has happened as an unplanned byproduct of a shift in priorities by the Foundation for Research, Science and Technology towards more research on biosecurity and sustainable urban development. The Foundation said yesterday that it was lifting biosecurity research from $\$ 800,000$ to $\$ 4.7$ million a year and spending another $\$ 4.7$ million on 'sustainable cities' " (Collins, 2003). New Zealand's business weekly, The Independent, censured the funding decision saying that social engineering was being funded at science's expense (The Independent, 2003).

Influential people in the agricultural sector spoke out. A. Freeth, then chief executive of Wrightson, New Zealand's oldest and largest agricultural firm and private agricultural research group (Brower, 2005), said in the Country-Wide Northern (2003, p. 52), "Policy [is] skewed too far towards commercialisation at the expense of applied research. What we're seeing is institutions that previously haven't had to chase after money hustling for the sexy stuffbiotech." "[T] raditional research by the likes of soil scientists, parasitologists, and biologists is being restructured out of existence because the CRIs and Universities say they don't have the funds for them. So many scientists and officials I meet have become less concerned with the science or teaching the core disciplines and focused, to obsession, with business and company structures, equity stakes, IP ownership, investment proposals, and joint ventures...' follow the money' mentality is not the fault of the institutions but the policy signals they receive from FRST (Foundation for Research, Science and Technology) and ultimately government."

The Regional Councils, endusers of research by the CRIs, spoke out against the funding decision. One Regional Council said, on the condition of anonymity, it "will not have the added benefits of a better understanding of our own resources." It cited "no coherent strategy or priority for national sustainability research."

The General Managers of the four most affected CRIs (AgResearch, Crop and Food Research, HortResearch, and Landcare Research), both individually and collectively, recognized a serious problem and showed early leadership. The General Managers commissioned one of us, soil scientist B. Clothier (Science Leader, Environment Sector of HortResearch), to investigate the purchasing failures and recommend a solution. They asked for a confidential report, which they could present to their CEOs as well as their colleagues in the Association of Crown Research Institutes (ACRI). ACRI is run by a board consisting of the CEOs of all nine CRIs. Its purpose is to grow the business of the CRIs.

The confidential report that was prepared was entitled "A Cross-CRI Sustainability Partnership. A Positioning Analysis and Proposition" (not in the public domain). The report's findings were that perceptions and reality did not coincide. The perceptions were: 1) there is no land-use policy to underpin purchase; 2 ) primary production is a "sunset" industry; 3 ) there are duplicated provider capabilities; 4 ) there is sufficient capacity to carry out research; and 5 ) the research cut by FRST was "old science." The reality was: 1 ) there was no national perspective on sustainable land use; 2) primary production was the economic engine of the decade; 3 ) there were fragmented provider capabilities; 4) a thin "babyboomer" line of "white coats" (researchers) existed; and 5) there were new imperatives and innovative tools. The report pointed out that provider capabilities were spread across the four CRIs in an unlinked way. The report's solution was to consolidate the fragmented capability and create a Cooperative Crown Center. The four Crown Research Institutes could, Clothier suggested, join together in cooperative research to maintain and manage soil and land use in New Zealand. The solution was presented at an ACRI forum, and FRST was provided with a copy of the report.

The media outrage no doubt put FRST, the independent purchaser on 
behalf of the government, under pressure. The public outcry probably also put pressure on FRST through elected members of Parliament. With a solution at hand (the Cooperative Crown Center), FRST worked out a means to accept it.

From the Cooperative Crown Center concept developed SLURI. It is a virtual national center for maintaining the research capacity to manage New Zealand's soils. The government began funding the center on 1 Oct. 2004 with NZ \$2.5 million per year of long-term funding. The national center brings together the best teams to research soil and land use. The CRIs now collaborate when appropriate. The center integrates biophysical research, socioeconomic considerations, and policy. It involves key stakeholders in its governance and priority setting. They include industry personnel (e.g., Fonterra, the milk company; VegFed; Fruitgrowers; NZ Wine; and Meat and Wool NZ), local government (the Regional Councils), and central government (Ministry of Agriculture and Forestry and Ministry for the Environment).

In summary, in 2003 funding for soil and land-use research was cut by FRST, yet individual scientists could not speak to the press. Funding was reestablished because of pressure from outside voices of support, the proposition of an internal solution, and the assent of government. Also, FRST probably restored funding in response to calls from editorials in New Zealand's leading newspaper, influential agricultural businesses, and governmental ministers.

\section{Current initiatives in the U.S. to maintain funding}

Funding of agricultural research in the U.S. has not yet taken the route of New Zealand (F.A. Cholick, personal communication, 3 July 2006). The cuts proposed by the U.S. President for fiscal year 2006 did not take place. The U.S. President's fiscal year 2006 budget would have cut the Hatch (agriculture) and McIntireStennis (forestry) research programs by $50 \%$ in fiscal year 2006 and zeroed them out in fiscal year 2007. The U.S. President proposed that the $50 \%$ cut in formula funds be put into competitive grants. Administrators from National
Association of State Universities and Land-Grant Colleges (NASULGC), including F.A. Cholick, then chair of the Budget and Advocacy Committee of NASULGC (NASULGC, 2006a), went to the U.S. Congress in 2005 and told the legislators that the U.S. President's fiscal year 2006 budget was unacceptable. The U.S. President's proposal was defeated and the status quo was maintained. However, the status quo was a cut because of inflation. Details of the agricultural budget, including the reports of the U.S. House of Representatives and Senate, are available at NASULGC (2006a).

In addition to the administrators of NASULGC and representatives of the various land-grant institutions, people appointed to the Council on Agriculture Research, Extension, and Teaching (CARET) also participated in the visits to the U.S. Congress. This was an important group, because it is comprised of those engaged in agriculture in each state (e.g., farmers, ranchers, and processors) (NASULGC, 2006a). They are the endusers of the research and extension programs and the graduates of the teaching programs. They are the constituents who vote for members of the U.S. Congress.

Preserving the land-grant system is essential for two key reasons (F.A. Cholick, personal communication, 3 July 2006). First, with competitive grants, a permanent base of scientists would not be available. For example, if a plant disease suddenly becomes prevalent, a core of plant pathologists is necessary to study it. We do not know what the problems of the future will hold, but we need the capacity to study them. Second, the strength of the land-grant system is its extensiveness. Agricultural research is not done in a few institutions, but in each of the 50 states of the U.S. This network allows prompt response to a problem such as soybean rust (Phakopsora pachyrhizi). When it was discovered in the southern U.S., all the agricultural laboratories in the U.S. knew about the threat immediately.

To avoid budget cuts and restructuring that would hamper the scientific community's ability to respond to agricultural problems, as occurred in New Zealand, the Policy Board of Directors of NASULGC's Board on Agriculture Assembly (BAA) formed a "think tank" group in 2005 to review the USDA land grant partnership and recommend a New Partnership Framework (NASULGC, 2006b). The think tank group was renamed the CREATE-21 committee. CREATE-2l stands for "Creating Research, Extension, and Teaching Excellence for the 21st Century." The CREATE-2l committee has three cochairs: F. Cholick, J. Armstrong, and L. Lyons. The CREATE-21 committee recommends that present internal and external research, extension, and education efforts within the USDA be integrated within a national institute. The national institute would be formed through the consolidation of agencies, programs, and activities currently within the USDA's Research, Education, and Economics Mission Area (REE) and U.S. Forest Service (USFS) R\&D. U.S. food, agriculture, and natural resources research programs are currently divided among three USDA agencies: 1) the Agricultural Research Service (ARS), 2) the Cooperative State Research, Education, and Extension Service (CSREES), and 3) USFS R\&D. As a result, there is frequently duplication among the agencies, no clearly identified lead agency to address critical national issues (such as the relationship of food and nutrition to obesity), and a lack of integration across agencies. The national institute would eliminate much of the overlap among program areas within ARS, CSREES, and USFS R\&D (NASULGC, 2006b).

The authorization of new funds is an integral element of CREATE-21. The U.S. is not keeping pace with other nations, most notably China and India, when it comes to public expenditures on food, agriculture, and natural resources. Statistics released by the Food and Agriculture Organization of the United Nations' (FAO) Science Council in Dec. 2005 show that India and China increased public agricultural R\&D spending from 1981 to 2000 by $248 \%$ and $200 \%$, respectively, whereas spending in the U.S. grew by only $51 \%$ (NASULGC, 2006b). The national institute would assume all of the land-grant support functions currently managed by CSREES, including administration of the formula funds and competitive programs. The national institute would be authorized to receive two categories of funds: 1) capacity funds and 2) competitive 
funds. The capacity funds would provide basic support for the laboratories and facilities run by the USDA (intramural) and the research, teaching, extension, and international programs run by USDA's land-grant and related university partners. The concepts put forth by CREATE-21 will be voted on in Aug. 2006 by the official voting delegates of NASULGC's BAA. The National Institute proposed by CREATE-2l is similar to SLURI, the national center for soil science research in New Zealand, albeit on a larger scale. The national institute of the USDA would include all agricultural research in the U.S.

\section{Final comments}

The biggest deficiency in new public management comes from designing a system based on a narrow set of ideas and not using the available science of an organization. That is, the soil scientists in New Zealand were not funded in the 2003 budget. Their skills would not have been available to solve soil and land-related problems in New Zealand had funding for them not been reestablished. The need to maintain core capability is one of the goals of the CREATE-21 Committee of NAGULGC, BAA. "Requisite variety" must be maintained in funding science. Ashby's law of requisite variety (Ashby, 1956, p. 206) states that the regulator must have as much or more variety than the system it regulates. The New Zealand science funding system failed when it funded only "glamorous sectors" (Dann, 2003) and eliminated support for traditional science that underpins the economy and scientific development. For example, if funding for geography had been ended 20 years ago, as some proposed (geography was then considered an "old science"), the new area of geographic information systems (GIS) might not have evolved.

New public management assumes an economic framework in which all agents act in their own self-interests rather than those of the public. The solution, given this premise, is to constrain agents (i.e., scientists) by contracts from principals (i.e., governmental funding agencies). The implication is that principals must know enough to set contracts, and the result was instability with longtime funding cuts for key scientists. An alternative to new public management is one in which the agents (i.e., scientists) are assumed to be trustworthy and mostly act in the public interest. New Zealand's new national soil center (SLURI) shows this possibility. In addition, one must recognize the asymmetry of knowledge and dollars is so large that there have to be several layers to make choices. Information needs to move upward to government from individual scientists, and information needs to move downward to the scientists from government. One must apply appropriate decision-making at all levels but still use contracts with strict adherence to the Public Finance Act and clear accountability for expenditures of public money.

\section{Literature cited}

Ashby, W.R. 1956. An introduction to cybernetics. Wiley, N.Y.

Boden, R., D. Cox, M. Nedeva, and K. Barker. 2004. Scrutinising science. The changing UK government of science. Palgrave Macmillan, N.Y.

Brower, V. 2005. Biotechnology in Australia and New Zealand. Genet. Eng. News 25:21, 22, 40.

Cerf, V. and H.N. Miller. 2005. America gasps for breath in the R\&D marathon. Wall Street J. 27:A12.

Cloyd, R.A. 2005. Challenges to extension programming. HortTechnology 15:177-180.

Collins, S. 2003. Exodus of soil 'giants' tipped. 24 Aug. 2006. <http://www. nzherald.co.nz/storyprint.cfm? storyID= 3521345>.
Country-Wide Northern. 2003. Research focus skewed too far towards product outcomes says Wrightson chief. Aug. 2003:52.

Dann, L. 2003. Land being squeezed on research. 24 Aug. 2006. <http://www. nzherald.co.nz/storyprint.cfm? storyID= $3523472>$.

Hawken, P., A. Lovins, and L.H. Lovins. 1999. Natural capitalism. Little, Brown, N.Y. and Boston

Judd, W. 2005. The haemorrhaging knowledge economy. N.Z. Geography $72: 2-3$

Ministry of Research, Science and Technology. 2006. About MoRST. 24 Aug. 2006. <http://http://www.morst. govt.nz/about $>$.

National Association of State Universities and Land-Grant Colleges. 2006a. 3 July 2006. <http://www.nasulgc-bac.com>.

National Association of State Universities and Land-Grant Colleges. 2006b. CREATE-21. 3 July 2006. <http:// www.create-21.org $>$.

Pelosi, N. 2006. R\&D Democrats. Wall Street J. 13 Feb.:Al6.

Tallon, J. 2005. Funding research in New Zealand. N.Z. Geography 72:8-10.

The Independent. 2003. Social engineering funded at science's expense. The Independent 24 Sept.:12.

The New Zealand Herald. 2003. Editorial: Soil sciences funding cut harms nation. 24 Aug. 2006. <http://www. nzherald.co.nz/storyprint.cfm? storyID= $3521758>$.

U.S. Central Intelligence Agency. 2006. New Zealand. 24 Aug. 2006. <https:// www.cia.gov/publications/factbook/ geos/nz.html>.

Williams, P., G. Francis, M. Lawton, A. Hewitt, I. Ferguson, B. Clothier, P. Benfell, and L. Wedderbum. 2005. Sustainable land use research initiative (SLURI). A national centre for maintaining and managing our soils. Crop and Food Research, Landcare Research, HortResearch, and AgResearch, Palmerston North, New Zealand. 